\title{
Analisis Sifat Fisis dan Ketahanan Atas Natrium Sulfat Paving Block dengan Variasi Serbuk Cangkang Langkitang (Faunus ater) dan Penambahan Serat Ijuk (Arrenge pinnata)
}

\author{
Mutia Sukma Dewi, Alimin Mahyudin* \\ Laboratorium Fisika Material, Jurusan Fisika \\ Fakultas Matematika dan Ilmu Pengetahuan Alam Universitas Andalas \\ Kampus Unand Limau Manis, Padang, 25163 Indonesia \\ *aliminmahyudin@fmipa.unand.ac.id
}

\begin{abstract}
ABSTRAK
Telah dilakukan analisis sifat fisis dan ketahanan terhadap natrium sulfat paving block dengan variasi serbuk cangkang langkitang dan penambahan serat ijuk. Persentase serbuk cangkang langkitang yang digunakan dalam agregat halus yaitu $0 \%, 10 \%$, dan $20 \%$. Persentase serat yang digunakan sebagai bahan tambahan sebesar $0 \%, 1 \%, 3 \%$, dan 4\% dengan penyusunan serat secara acak (randomly oriented). Pengujian yang dilakukan yaitu uji sifat fisis berupa kuat tekan, kuat lentur, daya serap air dan pengujian ketahanan terhadap natrium sulfat. Pengujian dilakukan setelah paving block berumur 28 hari. Kuat tekan dan kuat lentur diuji menggunakan Universal Testing Machine (UTM) PP 24-1283. Kuat tekan tertinggi sebesar $18,500 \mathrm{kN}$ diperoleh pada paving block dengan persentase serbuk cangkang langkitang $20 \%$ dan serat ijuk $10 \%$. Kuat lentur tertinggi diperoleh pada sampel dengan persentase serbuk cangkang langkitang $10 \%$ dan ijuk $1 \%$ dan $3 \%$ dan serbuk cangkang $20 \%$ serat ijuk 4\%. Daya serap air rerata terendah sebesar 0,0033\% dengan persentase serbuk cangkang langkitang 0\% dan serat ijuk 3\%. Kehilangan massa terbesar paving block setelah direndam menggunakan natrium sulfat terjadi pada persentase serbuk cangkang langkitang 20\%. Penggunaan serbuk cangkang langkitang sebagai agregat pengganti pasir menyebabkan penurunan kuat tekan paving block, namun ketika serbuk cangkang langkitang digunakan sebagai agregat tambahan mampu meningkatkan kuat tekan paving block. Berdasarkan kuat tekannya rata-rata paving block yang dibuat memenuhi standar mutu C hingga mutu B SNI 3-0691-1996.
\end{abstract}

Kata kunci: paving block, cangkang langkitang, serat ijuk, kuat tekan, kuat lentur, uji natrium sulfat, daya serap.

\begin{abstract}
Analysis of physical properties and resistance to sodium sulfate has been carried out for paving block with varying concentration of langkitang shell powder. The percentage of langkitang shell powders used in fine aggregates was $0 \%, 10 \%$, and $20 \%$, and the percentage of additives fibers random oriented was $0 \%, 1 \%, 3 \%$, and 4\%. Physical properties compressive such as strength, flexural strength, and absorption and sodium sulfate resistance were measured when samples aged 28 days. Stress and compressive strength were tested using Universal Testing Machine (UTM) PP 24-1283. The highest compressive strength $18,500 \mathrm{kN}$ was obtained for sample of with the percentage of langkitang shell powder of $20 \%$ and palm fiber $10 \%$. The Highest flexural strength was obtained for sample percentage of shell powder $10 \%$ and fibers $1 \%$ and $3 \%$ and shell powder $20 \%$ palm fiber $4 \%$. the lowest average water absorption rate in paving block on the percentage of $0 \%$ crushed luster powder and $3 \%$ palm fiber is 0.003. The largest mass loss of paving block after being immersed using sodium sulfate occurs in the percentage of 20\%. The use of shell powder as a sand substitute aggregate causes a decrease in the compressive strength of paving blocks, but when the shell powder is used as an additional aggregate it increases the compressive strength of paving blocks. The compressive strength of paving blocks meets the C to B quality standarof SNI 3-0691-1996.
\end{abstract}

Keywords: paving block, langkitang shells, palm fiber, compressive strength, flexural strength, sodium sulfate test, absorption.

\section{PENDAHULUAN}

Pesatnya pembangunan jalan di Indonesia mengakibatkan meningkatnya kebutuhan akan material penutup tanah, salah satunya paving block. Paving block biasa digunakan pada trotoar, halaman rumah, arena bermain, dan penutup permukaan lain. Penggunaan paving block sangat mendukung program go green yang telah dikampanyekan secara global karena daya serap air pada pemasangan paving blockberongga dapat memaksimalkan daya serap air tanah (Adibroto, 2014). Banyaknya penggunaan paving block mengakibatkan peningkatan kebutuhan 
material pembentuk paving block yang terdiri dari pasir, semen, dan air. Pasir yang digunakan dapat diganti dengan agregat halus lain. Penganti pasir misalnya nikel yang dilindi(Haque, 2016), tanah dan abu sekam padi (Sherliana dkk, 2016), limbah keramik (Penteado dkk, 2016), abu terbang dan lumpur lapindo (Alfianyah, 2017). Material lain seperti serat dapat digunakan sebagai material tambahan dalam pembuatan paving block karenaserat mempunyai kekuatan tarik yang cukup tinggi sehingga dapat mengurangi retak dini.

Penambahan material buatan pada paving block sudah diteliti, seperti penambahan serat ijuk dan penggunaan limbah adukan beton sebagai pengganti pasir (Perdana, 2012). Pada penelitian tersebut penambahan serat ijuk dan limbah adukan beton hanya menghasilkan paving block tipe $\mathrm{D}(10 \mathrm{MPa})$ karena menggunakan bahan limbah dan penambahan serat ijuk hanya mencapai 3\%. Susilowati dkk (2106) menemukan bahwa serat sabut kelapa menurunkan kuat tekan. Secara umum penambahan agregat halus dengan serat atau tanpa serat belum memenuhi standar SNI 03-06910-1996 mutu A (40 MPa),danmutu B (20 MPa).

Selain serat bahan tambahan pada paving blockberupa abu terbang dan lumpur lapindo menghasilkan paving block mutu C (12 MPa), penambahan abu sekam padi menghasilkan kuat tekan memenuhi standar SNI 03-06910-1996 mutu D, penambahan cangkang kerang (Kusuma, 2012) dengan campuran $80 \%$ pasir dan kulit kerang 20\%menghasilkan paving block dengan kuat tekan sebesar $46.79 \mathrm{MPa}$. Hal ini mengindikasikan bahwa paving block dengan campuran cangkang kerang sudah memenuhi SNI 03-06910-1996 paving block mutu A ( $40 \mathrm{MPa}$ ) dengan kandungan air 2,94\%, yang berarti memiliki kandungan air sedikit sehingga paving block tidak mudah rapuh.

Berdasarkan referensi diatas, maka serbuk cangkang langkitang dijadikan sebagai agregat tambahan pengganti agregat halus (pasir). Langkitang (faunus ater) adalah spesies dari kelas gastropoda yang memiliki cangkang kuat. Penambahan serat ijuk dapat menambah kuat lentur paving block sehingga diharapkan dapat mengurangi retak pada paving block (Wiryawan, 2008). Dalam penelitian ini akan dianalisis pengaruh serbuk cangkang langkitangdan serat ijuk untuk bahan campuranpaving block. Penggunaan bahan ini diduga lebih efektif karena serbuk cangkang langkitang bisa sebagai bahan tambahan agregat halus yang lebih kuat untuk mengisi pori-pori paving block dan penambahan serat dapat meningkatkan kuat lentur paving block. Tujuan dari penelitian ini adalah menganalisis sifat fisis paving block dan ketahanannya terhadap natrium sulfat dengan variasi serbuk cangkang langkitang dan penambahan serat ijuk. Hasil penelitian ini diharapkan dapat menghasilkan paving blockyang kuat, mengurangi limbah cangkang langkitang dan memaksimalkan penggunaan ijuk. Dengan tersedianya informasi tentang langkitang dan serat ijuk sebagai alternatif agregat tambahan pembuatan paving block, maka penelitian ini diharapkan menghasilkan paving block dengan mutu A sesuai standar SNI 06-091-1996.

\section{METODE}

Penelitian ini menggunakan metode eksperimen dengan pengujian daya serap dan tahan asam di Laboratorium Fisika Material Jurusan Fisika, Fakultas Matematika dan Ilmu Pengetahuan Alam. Pencetakan paving block di UD Riak Danau, Taruko, Padang. Pengujian agregat halus, kuat tekan, dan kuat lentur di Laboratorium Material dan Struktur Jurusan Teknik Sipil, Fakultas Teknik Universitas Andalas.

\subsection{Pengambilan dan Persiapan Cangkang Langkitang dan Serat Ijuk}

Agregat halus yang digunakan berasal dari cangkang langkitang yang diambil dari pedagang langkitang di Kota Pariaman. Cangkang langkitang dibersihkan dengan air mengalir kemudiandihancurkan menggunakan mesin Los Angeles sehingga didapatkan butiran halus dengan ukuran lolos saringan $4,750 \mathrm{~mm}$. Serat ijuk diambil dari pelepah pohon aren di Kota Pariaman kemudian diukur jari- jari kurang dari 0,45 $\mathrm{mm}$ dan dipotong-potong dengan panjang $2,5 \mathrm{~cm}$. 


\subsection{Persiapan Bahan Campuran}

Bahan campuran yang digunakan untuk pembuatan paving block antara lain: air, semen, serbuk cangkang langkitang, serat ijuk, dan natrium sulfat

\subsection{Pengujian Agragat Halus} C $128-04$.

Agregat halus diuji nilai specific gravity, absorbsidan berat isinya sesuai dengan ASTM

\subsection{Analisa Saringan}

Agregat halus minimal 500 gram disaring dengan satu set saringan $4,750 \mathrm{~mm}, 2,360$ $\mathrm{mm}, 1,190 \mathrm{~mm}, 0,595 \mathrm{~mm}, 0,270 \mathrm{~mm}$, dan0,147 mm(Standar ASTM C 33-92a) untuk mendapatkan gradasi agregat dengan menggunakan Persamaan 1 dan pada pemeriksaan kadar lumpur agregat halus diuji dengan pemeriksaan banyak sampel yang lewat saringan no. 200 (ASTM C 117-04) dengan menggunakan Persamaan 2.

$$
F M=\frac{\Sigma(\% T K S)}{100}
$$

FM merupakan jumlah gradasi agregat dan TKS merupakan jumlah sampel tertahan komulatif

$$
Z=\frac{w_{1}+w_{2}}{w_{1}} \times 100 \%
$$

$\mathrm{Z}$ merupakan banyak sampel yang lewat saringan no. 200, $w_{1}$ merupakan massa benda uji semula (g) dan $w_{2}$ merupakan massa bahan tertahan saringan No.200 (g).

\subsection{Pembuatan paving block}

Paving block dibuat berukuran $20 \mathrm{~cm} \times 10 \mathrm{~cm} \times 8 \mathrm{~cm}$ dan massa rata-rata $3 \mathrm{~kg}$. Paving block dibuat dengan perbandingan campuran semen dan agregat halus adalah 1:4,5. Agregat halus yang digunakan adalah pasir dan serbuk cangkang langkitang dengan variasi massa 5\%, $10 \%$, dan 20\%. Variasi serat ijuk adalah 0\%, 1\%, 3\%, dan 4\%. Paving block sebagai dibuat dengan pencampuran semen, air, pasir dan serbuk cangkang langkitang, kemudian paving block dicetak dan dipadatkan dengan metode pressing.

\subsection{Pengujian kuat tekan}

Pengujian kuat tekan dilakukan berdasarkan standar SNI 03-0691-1996. Benda uji ditekan dengan UTM hingga hancur, kecepatan penekanan dan beban yang diberikan dapat diatur dalam waktu 1 sampai 2 menit. Skala yang tertera pada benda uji dicatat dan kemudian dilakukan perhitungan dengan menggunakan Persamaan 3.

$$
F_{c}=\frac{P}{A}
$$

$F_{c}$ merupakan kuat tekan benda uji (MPa), $P$ merupakan beban maksimum ( $\mathrm{N}$ atau kN), dan $A$ merupakan luas penampang benda uji $\left(\mathrm{mm}^{2}\right)$

\subsection{Pengujian Kuat Lentur}

Pengujian kuat lentur dilakukan dengan metode third point loading sesuai standar SNI 03-4431-1997. Benda uji yang sudah mengeras diukur dimensinya dengan menggunakan mistar, kemudian diberikan beban pada dua titik yang membagi 3 jarak beban sama besar, pembebanan dilakukan kontinu sampai terjadi runtuhan. Untuk pengujian dimana patahnya benda uji ada di daerah pusat pada $1 / 3$ jarak titik perletakan pada bagian tarik dari beton, maka kuat lentur beton dihitung menurut Persamaan 4.

$$
R=\frac{3 p l}{b d^{2}}
$$


$R$ merupakan modulus of rupture, $p$ merupakan beban maksimum $(\mathrm{N}), l$ merupakan panjang bentang $(\mathrm{mm}), b$ merupakan rata- rata lebar benda uji $(\mathrm{mm})$, dan $d=$ rata-rata ketinggian benda uji (mm).

\subsection{Pengujian Penyerapan}

Benda uji ditimbang, kemudian direndam hingga jenuh selama 24 jam, lalu ditimbang massa basahnya, lalu dikeringkan dalam oven selama 12 jam pada temperatur $100{ }^{\circ} \mathrm{C}$. Setelah itu dilakukan perhitungan penyerapan air menggunakan Persamaan 5.

$$
\text { Penyerapan }=\frac{A-B}{B} \times 100 \%
$$

$A$ merupakan massa keadaan jenuh (kg) dan $B$ merupakan massa keadaan kering $(\mathrm{kg})$

\subsection{Pengujian Tahan Natrium Sulfat}

Pengujian tahan asam dengan cara menambahkan $0,8 \%$ natrium sulfat pada air rendaman paving block. Perhitungan untuk menetukan apakah paving block tahan atau tidak terhadap natrium sulfat digunakan Persamaan 5.

\section{HASIL DAN DISKUSI}

\subsection{Analisa Specific Gravity dan Absorbsi}

Nilai specific gravity serbuk cangkang langkitang dan pasir tidak jauh berbeda pada kondisi bulk specific gravity, SSD, dan apparent specific gravity penyerapan air pada serbuk cangkang langkitang dan pasir cukup baik yaitu sebesar 2,040\% dan 1,419\%. Nilai tersebut menandakan bahwa serbuk cangkang langkitang dan pasir memiliki daya serap yang baik yaitu tidak lebih dari $3 \%$.

\subsection{Pemeriksaan Berat Isi}

Berat isi pasir sebesar $1,211 \mathrm{~kg} / \mathrm{dm}^{3}$ dan berat isi langkitang $1,629 \mathrm{~kg} / \mathrm{dm}^{3}$, berdasarkan data tersebut nilai berat isi dari pasir dan langkitang sedikit berbeda yaitu dengan selisih 0,418 $\mathrm{kg} / \mathrm{dm}^{3}$,sehingga pasir bisa dijadikan agregat pengganti pasir karena berat isinya memiliki nilai yang hampir sama.

\subsection{Analisis Saringan}

Hasil analisis saringan didapatkan nilai fine modulus sebesar 0,986 untuk pasir dan 0,934 untuk serbuk cangkang langkitang, nilai ini menandakan bahwa butiran dari sampel agregat halus tersebut tergolong sangat halus.

\subsection{Pemeriksaan Agregat Halus Lewat Saringan No.200}

Hasil perhitungan bahan lewat saringan no.200 agregat halus berupa pasir adalah 5\% dan serbuk cangkang langkitang 12,4 \%. Berdasarkan ASTM C 117-04, persentasi jumlah agregat yang lewat saringan no.200 adalah $0,15 \%$, namun masih bisa diperbolehkan hingga $0,43 \%$ untuk agregat halus, dapat dikatakan bahwa agregat halus yang digunakan ini tidak sesuai ASTM C 117-04 dan mengandung lumpur.

\subsection{Kuat Tekan Paving Block}

Nilai kuat tekan paving block dengan variasi serbuk cangkang langkitang dan serat ijuk dapat dilihat pada Gambar 1. Kuat tekan pada paving block tanpa serbuk cangkang langkitang memiliki kuat tekan yang cenderung tidak beraturan seiring dengan penambahan serat ijuk. Nilai kuat tekan tertinggi terdapat pada paving block dengan persentase serbuk cangkang langkitang 20\% dan serat ijuk 1\% yaitu 18,500 MPa (mutu B SNI 03-0691-1996). Kuat tekan paving block terendah yaitu pada variasi serbuk cangkang langkitang $20 \%$ dan serat ijuk $4 \%$ sebesar 9,125 Mpa (mutu D SNI 03-0691-1996). Kuat tekan paving block yang tidak divariasikanserbuk cangkang langkitang lebih tinggi daripada yang divariasikan. Kuat tekan paving block mengalami penurunan seiring dengan penambahan persentase serbuk cangkang langkitang. Hal ini dikarenakan adanya perubahan ikatan pada material paving block. 


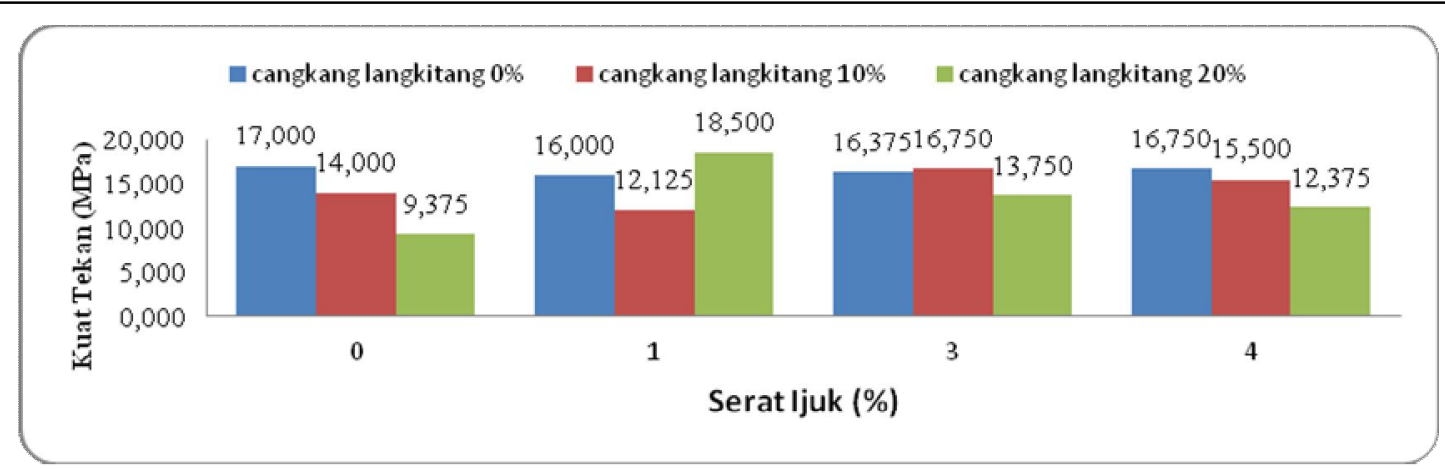

Gambar 1 Kuat tekan paving block dengan variasi serbuk cangkang langkitang dan penambahan serat ijuk

Serbuk cangkang langkitang bisa digunakan sebagai agregat tambahan seperti yang terlihat pada Gambar 2. Kuat tekan paving block dengan tambahan serbuk cangkang langkitang semakin meningkat seiring dengan penambahan serbuk cangkang langkitang. Kuat tekan ratarata paving block memenuhi standar mutu paving block mutu C (15 MPa), namun pada variasi serbuk cangkang langkitang $0 \%$ serat ijuk 0\% dan cangkang langkitang 20\% serat ijuk $1 \%$ memenuhi mutu B (20 MPa) standar SNI 03-0691-1996.

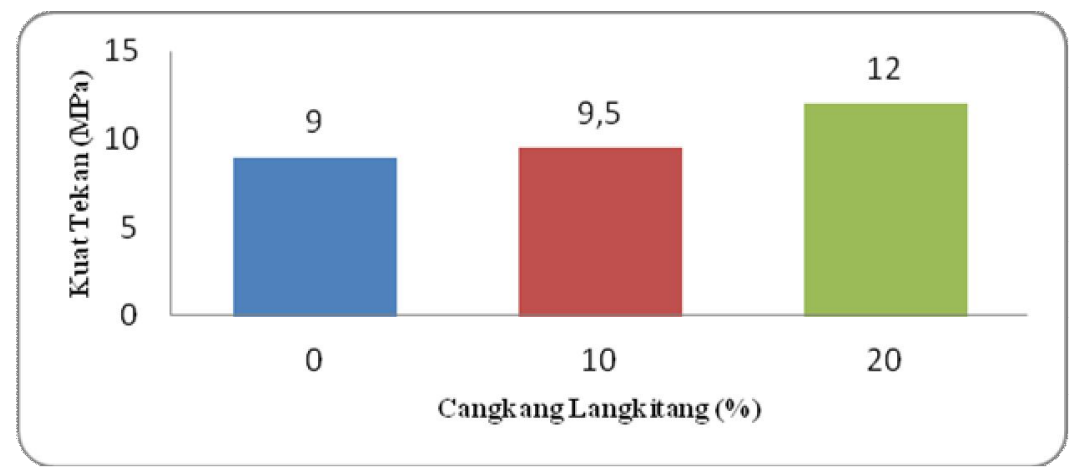

Gambar 2 Grafik kuat tekan paving block dengan tambahan serbuk cangkang langkitang

\subsection{Kuat Lentur Paving block}

Berdasarkan hasil pengukuran dan perhitungan didapatkan pengaruh serbuk cangkang langkitang dan serat ijuk terhadap kuat lentur paving block seperti pada Tabel 1. Paving block dengan variasi cangkang $0 \%$ dan $10 \%$ memiliki nilai kuat lentur yang sama seiring dengan penambahan serat ijuk, namun berbeda pada paving block dengan variasi serbuk cangkang langkitang 20\%. Pada variasi serbuk cangkang langkitang 0\% dan $10 \%$ penambahan serat ijuk dari $0 \%$ hingga $1 \%$ tidak menimbulkan kelenturan pada paving block, namun saat divariasikan serat ijuk 3\% menimbulkan kuat lentur hingga 3,515 MPa. Sedangkan pada paving block dengan variasi serbuk cangkang langkitang 20\% penambahan serat ijuk dari $0 \%$ hingga 3\% sama sekali tidak menimbulkan kelenturan pada paving block dan saat variasi serat ijuk $4 \%$ menimbulkan kuat tekan sebesar 3,515 MPa. Secara umum paving block ini memiliki nilai kuat kuat lentur konstan pada 3,515 dan ini merupakan nilai lentur maksimum. Pada SNI 03-06911996 bata beton (Paving block) tidak ada ketentuan kuat lentur untuk setiap mutunya dan tidak ada batasan minimal kuat lentur paving block berdasarkan mutunya. Jadi berdasarkan kuat lenturnya, paving block yang mengandung serbuk cangkang langkitang dan serat ijuk tidak dapat dimasukan kedalam kategori mutu pada SNI 03-0691-1996 bata beton (Paving block). 
Tabel 1 Kuat lentur paving block dengan variasi serbuk cangkang langkitang dan penambahan serat ijuk

\begin{tabular}{ccccc}
\hline $\begin{array}{c}\text { Cangkang } \\
\text { langkitang } \\
(\boldsymbol{\%})\end{array}$ & $\begin{array}{c}\text { Serat } \\
\text { ijuk } \\
(\boldsymbol{\%})\end{array}$ & $\begin{array}{c}\text { Beban } \\
\text { rata- } \\
\text { rata } \\
(\mathbf{N})\end{array}$ & $\begin{array}{c}\text { Persentase } \\
\text { selisih massa } \\
\text { uji } \mathbf{N a}_{\mathbf{2}} \mathbf{S O}_{\mathbf{4}} \\
\mathbf{( \% )}\end{array}$ & $\begin{array}{c}\text { Kuat } \\
\text { lentur rata- } \\
\text { rata } \\
\left(\mathbf{N} / \mathbf{m m}^{2}\right)\end{array}$ \\
\hline & 0 & 0 & 0 & 0,000 \\
0 & 1 & 0 & 0 & 0,000 \\
& 3 & 5 & 0,166 & 3,516 \\
& 4 & 0 & 0 & 0,000 \\
\hline & 0 & 0 & 0 & 0,000 \\
10 & 1 & 0 & 1,451 & 0,000 \\
& 3 & 5 & 0 & 3,516 \\
& 4 & 0 & 0,166 & 0,000 \\
\hline & 0 & 0 & 1,666 & 0,000 \\
& 1 & 0 & 0,165 & 0,000 \\
& 3 & 0 & 0 & 0,000 \\
& 4 & 5 & 1,557 & 3,516 \\
\hline
\end{tabular}

\subsection{Daya Serap Air}

Berdasarkan data dan hasil perhitungan didapatkan pengaruh variasi serbuk cangkang langkitang dan serat ijuk pada Gambar 3. Paving block dengan variasi serbuk cangkang $10 \%$ daya serapnya tidak terlalu jauh berbeda antara satu dengan yang lainnya seiring dengan pertambahan serat ijuk. Cangkang langkitang yang tidak divariasikan dengan serbuk cangkang langkitang dan serat ijuk memiliki daya serap yang lebih tinggi daripada yang divariasikan dengan serbuk cangkang langkitang dan serat ijuk. Penggunaan ijuk dengan persentase $4 \%$ juga mengakibatkan peningkatan daya serap air pada paving block dan menyebabkan penurunan kualitas pada paving block.Berdasarkan SNI 03-0691-1996 paving block dengan variasi serat ijuk $0 \%$ dan $4 \%$ yang memiliki persentase daya serap lebih dari 3\%, ini artinya paving block dengan persentase serat ijuk 1\%, 2\%, dan 3\% bisa dikategorikan mutu A dan pavingblock dengan persentase serat ijuk $1 \%$ dan $4 \%$ dikategorikan mutu B.

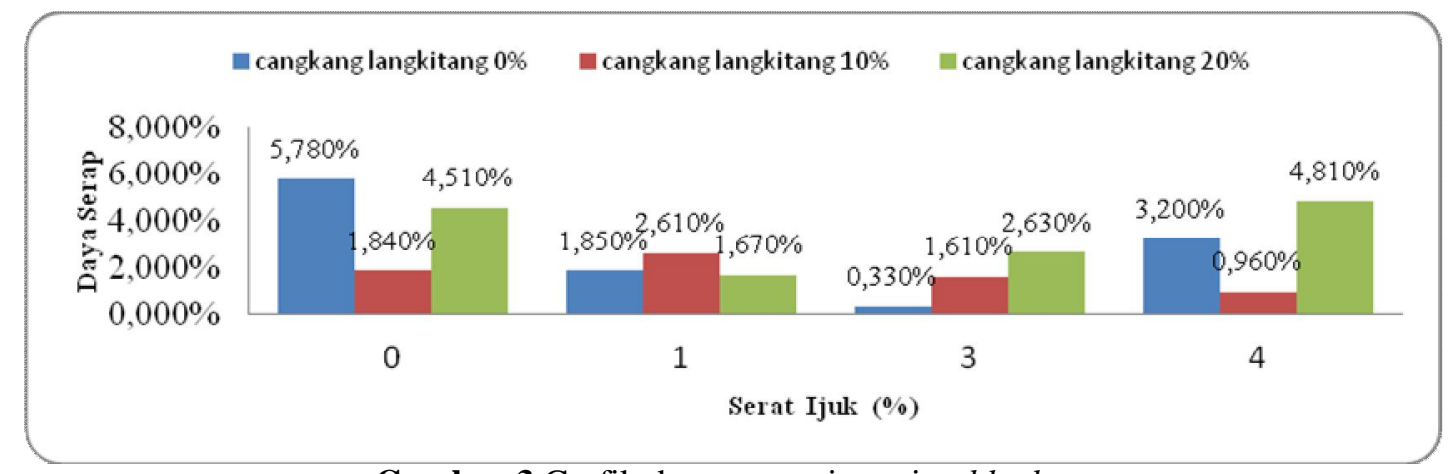

Gambar 3 Grafik daya serap air paving block

\subsection{Ketahanan Natrium Sulfat}

Berdasarkan hasil pengukuran dan perhitungan didapatkan pengaruh serbuk cangkang langkitang dan serat ijuk pada paving block pada Tabel 1. Paving blockyang paling banyak kehilangan massa setelah direndam dalam natrium sulfat pada persentase serbuk cangkang langkitang $20 \%$ dan 10\%, sehingga dapat dikatakan bahwa serbuk cangkang langkitang tidak tahan terhadap natrium sulfat. Berdasarkan SNI 03-069101996 paving block yang apabila diuji tidak boleh cacat, kehilangan massa yang diperkenankan adalah maksimum $1 \%$, dari data yang diperoleh paving blockyang divariasikandengan serbuk cangkang langkitang dan ijuk sudah memenuhi standar, namun seiring dengan penambahan serbuk cangkang langkitang selisih masa 
yang hilang juga semakin besar, sehingga paving block ini bisa dikatakan tidak tahan terhadap natrium sulfat.

\section{KESIMPULAN}

Berdasarkan penelitian yang telah didapatkan, dapat disimpulkan bahwa: agregat halus berupa pasir dan serbuk cangkang langkitang memiliki daya serap air yang cukup baik yaitu sebesar 2,040\% dan 1,419\%. Penggunaan serbuk cangkang langkitang sebagai agregat pengganti pasir menyebabkan penurunan kuat tekan paving block, namun ketika serbuk cangkang langkitang digunakan sebagai agregat tambahan mampu meningkatkan kuat tekan paving block. Paving block berdasarkan kuat tekannya rata-rata hanya memenuhi mutu $\mathrm{C}$ hingga mutu B SNI 3-0691-1996. Serat ijuk dapat meningkatkan kuat lentur paving block. Penyerapan paving block memiliki daya serap air rata-rata dibawah 3\% dan ini memenuhi standar mutu A SNI 03-0691-1996 bata beton (paving block). Serbuk cangkang langkitang tidak tahan terhadap natrium sulfat.

\section{DAFTAR PUSTAKA}

Adibroto, F., "Pengaruh Penambahan Berbagai Jenis Serat Pada Kuat Tekan Paving block", Jurnal Rekayasa Sipil, 10, 1, 1-11 (2014).

Alfianyah,"Pengaruh Penambahan Kapur Terhadap Kuat Tekan dan Permeabilitas Paving block Geopolymer Berbahan Dasar Abu Terbang dan Lumpur Lapindo", Jurnal Rekayasa Teknik Sipil 01,01, 412 - 423 (2017).

Badan Standarisasi Nasional (BSN), 1996, "Bata Beton (Paving block)", Indonesia, SNI 030691-1996.

Badan Standarisasi Nasional (BSN), 1997, "Metode Pengujian Kuat Lentur Normal Dengan Dua Titik Pembebanan". Indonesia, SNI 03-4431-1997..

Haque, M.A., "Assessment Of Nikel Leaching Phenomena From Landfill Waste Mixed Paving block For Eco-Friendly Field Application", Journal of Cleaner Production, 139, 99-112 (2016).

Kusuma, E.J., "Pemanfaatan Limbah Kulit Kerang Sebagai Bahan Campuran Pembuatan Paving block", Skripsi, Jurusan Teknik Lingkungan, UPN Veteran Jatim, (2012).

Munandar ,I., Savetlana, S., Sugiyanto, "Kekuatan Tarik Serat Ijuk (Arrenge pinnata)", Jurna lIlmiah Teknik Mesin, 1, 3, 52-58 (2013).

Penteado, C.S.G., Eduardo, E., V., Lintz, R., C., "Reusing Ceramic Tile Polishing Waste In Paving block Manufacturing", Journal of Cleaner Production, 11, 514-520 (2016).

Perdana, G.R., "Studi Sifat Mekanik Paving block Campuran Limbah Adukan Beton dan Bahan Tambahan Serat Ijuk", Skripsi, Jurusan Teknik Sipil Bidang Kekhususan Struktur, UI, (2012).

Sherliana, Iswan, Setyanto, 2016, "Studi Kuat Tekan Paving block dari Campuran Tanah, Semen, dan Adukan Abu Sekam Padi Menggunakan Alat Pemadat Modifikasi”, Jurnal Rekyasa Sipil dan Desain, 4, 1, 99-112 (2016).

Susilowati A., Simanullahng K.,A., danAprilia, L., "Bata Beton (Paving block) Geopolimer dengan Variasi Konsentrasi Serat Sabut Kelapa”, Jurnal Politeknologi, 15, (2016).

Wiryawan S., "Pengaruh Penambahan Serat Ijuk Pada Kuat Tarik Campuran Semen-Pasir dan Kemungkinan Aplikasinya", Jurnal Teknik Sipil, 8, 2, 159-169 (2008). 